\title{
Chemical Weathering in Streams in the Mount St Helens 1980 Blast Area
}

\author{
C.A. NEZAT ${ }^{1 *}$, S.R. KIMMIG ${ }^{2}$, T. BLACKMAN ${ }^{3}$ AND C.M. \\ CRISAFULLI ${ }^{4}$
}

${ }^{1}$ Department of Geology, Eastern Washington Univ., Cheney, WA 99004, USA (*correspondence: cnezat@ewu.edu)

${ }^{2}$ Pacific Northwest National Lab, Richland, WA 99354, USA (sara.kimmig@pnnl.gov)

${ }^{3}$ Mt Hood Environmental, PO Box 744, Boring, OR 97009, USA (tarablackman@mthoodenvironmental.com)

${ }^{4}$ US Forest Service, Pacific Northwest Research Station, Mount St. Helens National Volcanic Monument, Amboy, WA, 98601, USA (charlie.crisafulli@usda.gov)

Chemical weathering rates decrease as mineral surfaces age yet studying the initial stages of weathering in a natural setting is problematic due to the scarcity of young rocks at the surface of the earth. Recent volcanic eruptions provide an opportunity to investigate weathering processes altering young deposits in a natural setting. For example, the Mount St Helens (MSH) 1980 eruption and preceding landslide substantially altered the volcanic edifice and a $600 \mathrm{~km}^{2}$ area to the north. The powerful laterally-directed pyroclastic density current (PDC) removed, toppled and singed trees resulting in a largely denuded landscape. Later in the eruption sequence, multiple dacitic pyroclastic flows were deposited immediately north of the edifice, creating a vast sterile Pumice Plain.

To examine the chemical signatures of streams affected to varying degrees by recent volcanic eruptions, water samples were collected from 17 locations along eight streams in the Pumice Plain and in areas subjected to the blast PDC. Samples were analyzed for $\mathrm{Ca}^{2+}, \mathrm{Mg}^{2+}, \mathrm{Sr}^{2+}, \mathrm{Na}^{+}, \mathrm{K}^{+}$and $\mathrm{H}_{4} \mathrm{SiO}_{4}$ concentrations, and ${ }^{87} \mathrm{Sr} /{ }^{86} \mathrm{Sr}$ ratios.

Overall, the ${ }^{87} \mathrm{Sr} /{ }^{86} \mathrm{Sr}$ ratios of the waters $(0.703309$ 0.703683 ) are similar to the whole rock values of $1980 \mathrm{MSH}$ deposits. However, the ${ }^{87} \mathrm{Sr} /{ }^{86} \mathrm{Sr}$ ratios vary across the landscape. For example, ${ }^{87} \mathrm{Sr} /{ }^{86} \mathrm{Sr}$ ratios are more radiogenic (0.703633-0.703683) and elemental concentrations are lower in streams flowing across the area subjected to the blast PDC than in streams draining the young Pumice Plain. Additionally, the ${ }^{87} \mathrm{Sr} /{ }^{86} \mathrm{Sr}$ signatures of Pumice Plain streams differ among each other likely due to varying amounts of 1) surface and groundwater input, including springs, seeps and hyporheic exchange, and 2) relative rates of carbonate and silicate weathering. These preliminary results suggest that weathering rates are more rapid in streams draining the younger Pumice Plain compared to those draining the older substrate disturbed by the pyroclastic density current. 